\title{
Hepatitis $C$ seroprevalence among people living with HIV/AIDS and pregnant women in four provinces in Cambodia: an integrated bio-behavioral survey
}

Phearavin Pheng ${ }^{1,2^{*}}$, Laurence Meyer ${ }^{2}$, Olivier Ségéral ${ }^{1}$, Phalla Chea ${ }^{1}$, Siyan $\mathrm{Yi}^{3,4,5}$, Sovannary Tuot ${ }^{3,7,8}$, John M. Kaldor ${ }^{6}$ and Vonthanak Saphonn ${ }^{1}$

\begin{abstract}
Background: Understanding the extent of viral hepatitis burden in specific subgroups, such as pregnant women and people living with HIV/AIDS (PLWHA), and their geographic distribution is essential for evidence-informed policy and mobilizing resources for targeted treatment and prevention efforts. However, in Cambodia, the epidemiology of hepatitis $C$ remains uncertain. We estimated the hepatitis $C$ virus $(\mathrm{HCV})$ burden and transmission risk factors among PLWHA and pregnant women attending antenatal care (ANC) in Cambodia.
\end{abstract}

Methods: Between March and April 2016, we conducted a cross-sectional survey in four diverse geographical areas: the capital city of Phnom Penh and three provinces. We collected information on demographic characteristics and risk behaviors and performed HCV antibody (Anti-HCV) testing among pregnant women attending public ANC clinics and among those receiving HIV care at the hospitals. We computed the prevalence of HCV among the two population subsets and performed logistic regression analyses to identify risk factors associated with HCV antibody positivity.

Results: Of 935 participants enrolled, 510 (54.6\%) were pregnant women and 425 (45.4\%) were PLWHA. Anti-HCV prevalence was significantly higher in PLWHA than in pregnant women $(29 / 425,6.8 \%$ vs $5 / 510,0.9 \%, P<0.001)$. Of the geographic regions, Preah Sihanouk province (Southwest) had the highest anti-HCV prevalence among PLWHA $(12.0 \%, P=0.031)$. There was no significant geographic difference in anti-HCV prevalence among pregnant women. In multivariable analyses (data subset to PLWHA), HCV infection was significantly associated with having a family member positive for $\mathrm{HCV}(\mathrm{OR}=7.6$ [95\% Cl: 1.01-57.84], $P=0.048)$ and a history of intravenous medication injection in the last 5 years $(\mathrm{OR}=7.1[95 \% \mathrm{Cl}: 2.79-18.10], P<0.001)$.

Conclusions: HCV infection is relatively common among Cambodian PLWHA, likely related to intravenous medication injection and intra-familial viral transmission. Systematic HCV testing and care among PLWHA (and possibly their family members) might be necessary. Setting up a surveillance system for HCV might also be beneficial for some geographical regions and populations.

Keywords: HCV infection, Prevalence, People living with HIV/AIDS, Pregnant women, Cambodia

*Correspondence: phearavinpheng@uhs.edu.kh

1 University of Health Sciences, 73 Monivong Boulevard, Phnom

Penh 12201, Cambodia

Full list of author information is available at the end of the article

(C) The Author(s) 2022. Open Access This article is licensed under a Creative Commons Attribution 4.0 International License, which permits use, sharing, adaptation, distribution and reproduction in any medium or format, as long as you give appropriate credit to the original author(s) and the source, provide a link to the Creative Commons licence, and indicate if changes were made. The images or other third party material in this article are included in the article's Creative Commons licence, unless indicated otherwise in a credit line to the material. If material is not included in the article's Creative Commons licence and your intended use is not permitted by statutory regulation or exceeds the permitted use, you will need to obtain permission directly from the copyright holder. To view a copy of this licence, visit http://creativecommons.org/licenses/by/4.0/. The Creative Commons Public Domain Dedication waiver (http://creativeco mmons.org/publicdomain/zero/1.0/) applies to the data made available in this article, unless otherwise stated in a credit line to the data. 


\section{Background}

Hepatitis $\mathrm{C}$ virus (HCV) infection is a major public health concern, with an estimated 130-150 million chronic hepatitis $C$ virus infection worldwide [1] and 350,000 deaths each year due to hepatitis $\mathrm{C}$-related causes, mostly cirrhosis and hepatocellular carcinoma (HCC) [2]. The prevalence of $\mathrm{HCV}$ varies substantially around the world. The estimated global prevalence of $\mathrm{HCV}$ is 2-3\% [3] and $\sim 8 \%$ of pregnant women have HCV infection [1], with the highest prevalence in low- and middle-income countries (LMICs) in Africa and Southeast Asia [4]. The World Health Organization (WHO) Global Health Sector Strategy for Viral Hepatitis calls for the elimination of viral hepatitis by 2030 , aiming at a $90 \%$ reduction in incidence and a $65 \%$ reduction in mortality. To reach this target, $90 \%$ of chronic hepatitis cases need to be diagnosed, and $80 \%$ of eligible cases treated [1].

$\mathrm{HCV}$ treatment with direct-acting antivirals (DAA), is generally curative and success rates in LMICs are similar to those in high-income countries (HICs). Improved access to HCV testing and better epidemiological surveillance data are important steps in increasing $\mathrm{HCV}$ case detection and identifying those eligible for treatment. In particular, serological surveys can improve the understanding of the distribution of HCV infection in the general population and identify specific high-risk groups.

Globally, about 2.9 million people living with HIV/ AIDS (PLWHA) are co-infected with hepatitis $\mathrm{C}$ virus [1]. The major cause of morbidity and mortality among people co-infected with HIV and viral hepatitis is potentially related to liver diseases [5]. It is recommended that this population should be prioritized for screening and providing with an appropriate and effective treatment for both HIV and hepatitis. In Cambodia, addressing HCV infection in PLWHA could possibly be done through expending access to treatment for hepatitis $\mathrm{C}$ for people with HIV who are co-infected with HCV in the existing National HIV program. However, the epidemiology of hepatitis $\mathrm{C}$ remains uncertain, and prevalence data are limited with a wide variation in reported estimations among this population ranging from $7.6 \%$ [6] to $78.5 \%$ [7] and the data restricted in selective areas. The most atrisk population seems to be patients who have household member with liver disease, aged over 40 years old, possibly because of historical exposures to unsafe medical injections or transfusions [6-8].

In Cambodia, the HCV prevalence was high in people who inject drugs (30.6\%) [9] and low prevalence were found among young adult aged less than 45 years old (0.6\%) [10]. However, no data on the HCV prevalence among pregnant women are available in Cambodia. Due to the lack of appropriate laboratories and high cost of $\mathrm{HCV}$ testing and treatment, screening for HCV has not been routinely provided in health care settings including ANC clinics to prevent vertical transmission.

Despite there were a few studies on $\mathrm{HCV}$ prevalence among PLWHA in the past, the data have been limited to some selected areas (the Northwestern Cambodia and to a hospital-based cohort in the Capital city). Assessing viral hepatitis burden in other regions across the Cambodia to have broader understanding of the extent of viral hepatitis at the national level is essential to inform policy development and resource mobilization to address this infection.

In order to fill a knowledge gap in Cambodia, we undertook a study to estimate HCV burden and transmission risk factors in four provinces and two specific populations, PLWHA and pregnant women attending antenatal care (ANC) in Cambodia. This study attempted to assess the $\mathrm{HCV}$ prevalence rates in different regions across the country to have representative $\mathrm{HCV}$ prevalence rates for the overall population in Cambodia.

\section{Methods \\ Study design}

This study was an integrated bio-behavioral (cross-sectional) survey undertaken to assess the prevalence of $\mathrm{HCV}$ among PLWHA receiving HIV care at the ART clinics and pregnant women attending public ANC clinics in Cambodia.

\section{Study settings}

This study was carried out between March and April 2016 in antiretroviral therapy (ART) sites for PLWHA and in ANC clinics for pregnant women, located in four diverse geographical areas, including the capital city of Phnom Penh and three provinces in the West (Battambang), the Northwest (Siem Reap) and the Southwest regions (Preah Sihanouk) of Cambodia.

\section{Eligibility criteria}

Individuals were eligible for the survey if they were at least 18 years old and either living with HIV/AIDS and had visited the ART clinics or pregnant women who visited the public ANC clinics during the study period.

\section{Sample size, sampling and recruitment}

We used Open Epi software version 3 to calculate the sample size. Assuming the prevalence of $\mathrm{HCV}$ is $5 \%$ among pregnant women and $10 \%$ among PLWHA, to achieve a $2 \%$ margin of error for the pregnant women and $3 \%$ for PLWHA, power fixed at $80 \%$, at $5 \%$ alpha-level, a design effect of 1 , and a non-response rate of $10 \%, 502$ participants were required for pregnant women and 423 for PLWHA. 
A two-stage cluster sampling method was employed to select the eligible participants. Firstly, the probabilityproportional-to-size-sampling method was used to select 51 clusters (34/153 clusters for pregnant women and 17/21 clusters for PLWHA) from the selected geographical regions. A cluster was a health center for pregnant women and an ART clinic for PLWHA. Secondly, a consecutive sampling strategy was used to invite 15 pregnant women and 25 PLWHA from each cluster. Each participant signed the consent form if they agreed to participate in the study. The participants underwent face-to-face interviews using a structured questionnaire, following by a blood sample collection for HCV testing. Prior to data collection, all interviewers attended a training course to ensure they understood and followed standard procedures. The participants were only identified by a unique anonymous code (no identifiable information were collected). The code was use to link each participant to their sociodemographic information, their HCV results and their appointment sleep when they were back to the clinics to get their $\mathrm{HCV}$ results. The questionnaire was checked for completeness, accuracy and legibility, and validated questionnaires were sent to the University of Health Sciences (UHS) for data entry.

\section{Behavioral questionnaire}

The questionnaire was used to collect information on socio-demographic characteristics of participants such as age, sex, marital status, occupation and education. Multiple-choice questions were used to assess participants' knowledge, attitudes and practices related to $\mathrm{HCV}$ infection. The knowledge questions explored four broad dimensions: basic information about HCV infection, mode of transmission, vaccination and treatment availability. Information on potential risk factors of HCV infection included history of intramuscular and intravenous injections, blood transfusion, and cases of $\mathrm{HCV}$ in the household. For each question, participants were offered three response options: "No", "Yes" and "Don't know".

\section{Laboratory testing}

A $5 \mathrm{ml}$ blood sample was drawn from participants for $\mathrm{HCV}$ testing. Samples were kept at room temperature $\left(18-25{ }^{\circ} \mathrm{C}\right)$ for a maximum of $6 \mathrm{~h}$ and then sent to the UHS laboratory in Phnom Penh. After centrifugation, plasma specimens were stored at $-80{ }^{\circ} \mathrm{C}$ for analysis. $\mathrm{HCV}$ antibody testing was done with a third-generation (G3) HCV ELISA assay (MONOLISA ANTI HCV PLUS version 3, Bio-Rad), according to the manufacturer's instructions. Specimens showing a signal-to-cutoff $(\mathrm{SCO}) \geq 1$ were considered as positive for the anti-HCV antibody. Those with a SCO value $<1$ were considered negative. All samples with a $\mathrm{SCO} \geq 1$ were further tested to confirm chronic $\mathrm{HCV}$ infection with a commercial HCV RNA viral load (VL) assay (OMUNIS, Clapiers, France). All runs were done on Bio-Rad CFX96 real-time PCR machines (Bio-Rad). HCV genotyping was performed in NS5B gene, using an in-house semi-nested RTPCR and ANRS protocol.

\section{Statistical analyses}

The prevalence of $\mathrm{HCV}$ infection among pregnant women and among PLWHA were presented as percentages and $95 \%$ confidence intervals (CIs), computed using exact methods (for binomial distribution). Categorical variables were presented as frequencies and percentages, while continuous variables were described with means and standard deviation (SD). Comparisons of categorical variables between $\mathrm{HCV}+$ and $\mathrm{HCV}$ - participants across different socio-demographic and behavioral risk factors were performed using chi-squared or Fisher's exact tests accordingly. Multivariable logistic regression analysis was performed to identify risk factors associated with $\mathrm{HCV}$ antibody positivity. All non-collinear variables with a $P \leq 0.2$ in bivariate analyses or considered to be potential confounders based on previous studies were included in the models. Data were managed and analyzed using STATA 16 (StataCorp, USA), and $p$-values less than 0.05 were considered statistically significant.

\section{Results}

\section{Characteristics of study participants}

The characteristics of the 935 study participants (510 pregnant women and 425 PLWHA) are summarized in Table 1. The mean age of the participants was 42.9 years (SD, 9.3) for PLWHA and 27.6 years (SD, 5.3) for pregnant women. Approximately half of participants in both groups reported not having formal schooling or having Less than or primary school $(46.6 \%$ in PLWHA and $45.3 \%$ in pregnant women), about $98.0 \%$ of pregnant women and only $64.0 \%$ of PLWHA were married. More than half of participants in both groups were farmers/ self-employed and around $40 \%$ reported ever migrated to another country or to other places.

\section{Knowledge/attitudes on hepatitis $\mathrm{C}$ prevention and care}

Participants indicated high levels of willingness to get tested for $\mathrm{HCV}$ and to go for further investigations or treatment if $\mathrm{HCV}$ test positive. Correct answers to questions about whether blood should be screened for hepatitis $C$ before transfusion, and barbers should use new blades or safe equipment for ear and nose piecing were reported by more than $90 \%$ of participants in both groups (Table 2). 
Table 1 Characteristics of study participants by population group $(n=935)$, Cambodia, 2016

\begin{tabular}{|c|c|c|c|c|}
\hline \multirow[t]{2}{*}{ Characteristics } & \multicolumn{2}{|c|}{ PLWHA (N=425) } & \multicolumn{2}{|c|}{ Pregnant women $(\mathrm{N}=510)$} \\
\hline & $\mathbf{n}$ & $\%$ & n & $\%$ \\
\hline Mean age in years $( \pm S D)$ & $42.95( \pm 9.37)$ & & $27.68( \pm 5.33)$ & \\
\hline \multicolumn{5}{|l|}{ Age group, years } \\
\hline$\leq 30$ & 28 & 6.59 & 363 & 71.18 \\
\hline $31-40$ & 137 & 32.24 & 142 & 27.84 \\
\hline$>40$ & 260 & 61.18 & 5 & 0.98 \\
\hline \multicolumn{5}{|l|}{ Sex } \\
\hline Male & 189 & 44.47 & - & - \\
\hline Female & 236 & 55.53 & 510 & 100 \\
\hline \multicolumn{5}{|l|}{ Education } \\
\hline No formal schooling/less than or primary school & 198 & 46.59 & 231 & 45.29 \\
\hline Secondary school & 100 & 23.53 & 148 & 29.02 \\
\hline High school/University or higher & 127 & 29.88 & 131 & 25.69 \\
\hline \multicolumn{5}{|l|}{ Marital status } \\
\hline Never married & 37 & 8.71 & 10 & 1.96 \\
\hline Currently married & 272 & 64.00 & 499 & 97.84 \\
\hline Separated/divorced/widow & 116 & 27.29 & 1 & 0.20 \\
\hline \multicolumn{5}{|l|}{ Main occupation } \\
\hline Employee (Government/Non-government) & 111 & 26.12 & 110 & 21.57 \\
\hline Retired/unemployed/home duties & 76 & 17.88 & 129 & 25.29 \\
\hline Farmer/self-employed/others & 238 & 56.00 & 271 & 53.14 \\
\hline \multicolumn{5}{|l|}{ Residential mobility } \\
\hline Always live here & 240 & 56.47 & 328 & 64.31 \\
\hline Ever migrated (to another country/to other places) & 184 & 43.29 & 181 & 35.49 \\
\hline \multicolumn{5}{|l|}{ Geographic area } \\
\hline Battambang (West) & 75 & 17.65 & 165 & 32.35 \\
\hline Siem Reap (Northwest) & 75 & 17.65 & 135 & 26.47 \\
\hline Preah Sihanouk (Southwest) & 25 & 5.88 & 30 & 5.88 \\
\hline Phnom Penh (Central) & 250 & 58.82 & 180 & 35.29 \\
\hline
\end{tabular}

Table 2 Knowledge/attitudes on hepatitis prevention and care

\begin{tabular}{|c|c|c|c|c|}
\hline \multirow[t]{2}{*}{ Variables } & \multicolumn{2}{|c|}{ PLWHA (N=425) } & \multicolumn{2}{|c|}{ Pregnant women $(\mathrm{N}=510)$} \\
\hline & $\mathbf{n}$ & $\%$ & $\mathbf{n}$ & $\%$ \\
\hline Willing to get tested for hepatitis $C$ & 420 & 98.82 & 509 & 99.80 \\
\hline $\begin{array}{l}\text { Willing to go for further investigations or treatment if } \\
\text { HCV test positive }\end{array}$ & 423 & 99.53 & 509 & 99.80 \\
\hline Asking for or use a new/sterilized syringe or needle & 344 & 80.94 & 396 & 77.65 \\
\hline $\begin{array}{l}\text { Getting the blood screened for hepatitis } C \text { before } \\
\text { transfusion }\end{array}$ & 389 & 91.53 & 394 & 77.25 \\
\hline $\begin{array}{l}\text { Asking barber to use new blades or for safe equipment } \\
\text { for ear and nose piecing }\end{array}$ & 394 & 92.71 & 399 & 78.24 \\
\hline
\end{tabular}


Table 3 Healthcare and behavioral factors potentially related to hepatitis $C$ infection

\begin{tabular}{|c|c|c|c|c|}
\hline \multirow[t]{2}{*}{ Variables } & \multicolumn{2}{|c|}{$\begin{array}{l}\text { PLWHA } \\
(\mathrm{N}=425)\end{array}$} & \multicolumn{2}{|c|}{$\begin{array}{l}\text { Pregnant } \\
\text { Women } \\
(\mathrm{N}=510)\end{array}$} \\
\hline & $\mathbf{n}$ & $\%$ & $\mathrm{n}$ & $\%$ \\
\hline \multicolumn{5}{|l|}{ Healthcare and behavioral factors ${ }^{a}$} \\
\hline Ever been admitted to a hospital or clinic & 115 & 27.06 & 167 & 32.75 \\
\hline $\begin{array}{l}\text { Ever received intra-muscular medication } \\
\text { injection }\end{array}$ & 196 & 46.12 & 419 & 82.16 \\
\hline $\begin{array}{l}\text { Ever received intravenous medication } \\
\text { injection }\end{array}$ & 330 & 77.65 & 368 & 72.16 \\
\hline Ever received blood transfusion & 12 & 2.82 & 4 & 0.78 \\
\hline $\begin{array}{l}\text { Ever undergone any plastic surgery } \\
\text { procedure }\end{array}$ & 12 & 2.82 & 7 & 1.37 \\
\hline Ear/nose piercing or tattoo & 10 & 2.35 & 21 & 4.12 \\
\hline Ever visited dental clinic for dental care & 203 & 47.76 & 207 & 40.59 \\
\hline Ever used any illicit drug injection & 2 & 0.47 & 0 & 0.00 \\
\hline Having a family member positive for $\mathrm{HCV}$ & 31 & 7.29 & 20 & 3.92 \\
\hline \multicolumn{5}{|l|}{ HCV testing } \\
\hline Ever tested for viral hepatitis infection & 181 & 42.59 & 169 & 33.14 \\
\hline Ever tested for hepatitis $C$ & 85 & 20.00 & 27 & 5.29 \\
\hline
\end{tabular}

\section{Healthcare and behavioral factors potentially related to hepatitis $\mathrm{C}$ infection}

Within the past 5 years, high proportions of participants had received intravenous medication $(77.6 \%$ in PLWHA, $72.1 \%$ in pregnant women) or intramuscular injection $(46.1 \%$ in PLWHA, $82.1 \%$ in pregnant women), or visited the dentist (47.7\% in PLWHA, 40.5\% in pregnant women (Table 3 ).

\section{Prevalence of HCV infection}

HCV antibody prevalence was as high as (29/425) 6.8\% [95\% CI: 4.6-9.6] in PLWHA and was low (5/510) 0.9\% [95\% CI: 0.3-2.7]) in pregnant women. Of the 34 anti-HCV-positive individuals, 24 (70.6\%) had detectable HCV RNA, with substantially higher proportions of chronic infection in PLWHA compared to pregnant women (23/29) 79.3\% [95\% CI: 60.2-92.0] vs. (1/5) 20.0\% [95\% CI: $0.5-71.6$ ], $P=0.007$. A phylogenetic analysis of 24 samples with a detectable HCV RNA showed that (11/24) $45.8 \%$ were genotype $1 \mathrm{~b}$; $(1 / 24) 4.1 \%$ were genotype $2 \mathrm{a}$ and $(8 / 24) 33.3 \%$ were genotype $6(6: 4.1 \%$, $6 \mathrm{a}: 4.1 \%$, 6e:12.5\%, 6q:8.3\%, 6r:4.1\%) and $16.6 \%$ failed to amplify. In PLWHA, anti-HCV prevalence generally increased with age, from (1/28) 3.5\% [95\% CI: 0.0-18.3] in the youngest group (18-30 years) to (21/260) 8.0\% [95\% CI: 5.0-12.0] in the oldest group ( $>40$ years old), but the difference was not statistically significant $(P=0.51)$. In pregnant women, the anti-HCV prevalence was (4/363) 1.1\% [95\% CI: $0.3-2.7$ ] in the18-30 years age group and (1/142) $0.7 \%$ [95\% CI: $0.0-3.8$ ] in the $31-40$ years age group (Additional file 1: Table S1).

We observed that in PLWHA group, Preah Sihanouk province (Southwest) had the highest anti-HCV prevalence among the four studied geographic areas: Preah Sihanouk province (3/21) $12.0 \%$ [95\% CI: 2.5-31.2], Battambang (West) (2/75) 2.6\% [95\% CI: 0.3-0.9.3], Siem Reap (Northwest) (1/75) 1.3\% [95\% CI: 0.0-7.2], Phnom Penh (Central) (23/250) 9.2\% [95\% CI:5.9-13.4] (Fig. 1). There was no significant difference in anti$\mathrm{HCV}$ prevalence across the four regions in pregnant women.Fig. 1 Geographical distribution of HCV prevalence among PLWHA $(n=425)$ AND pregnant women $(n=510)$ in Cambodia, 2016

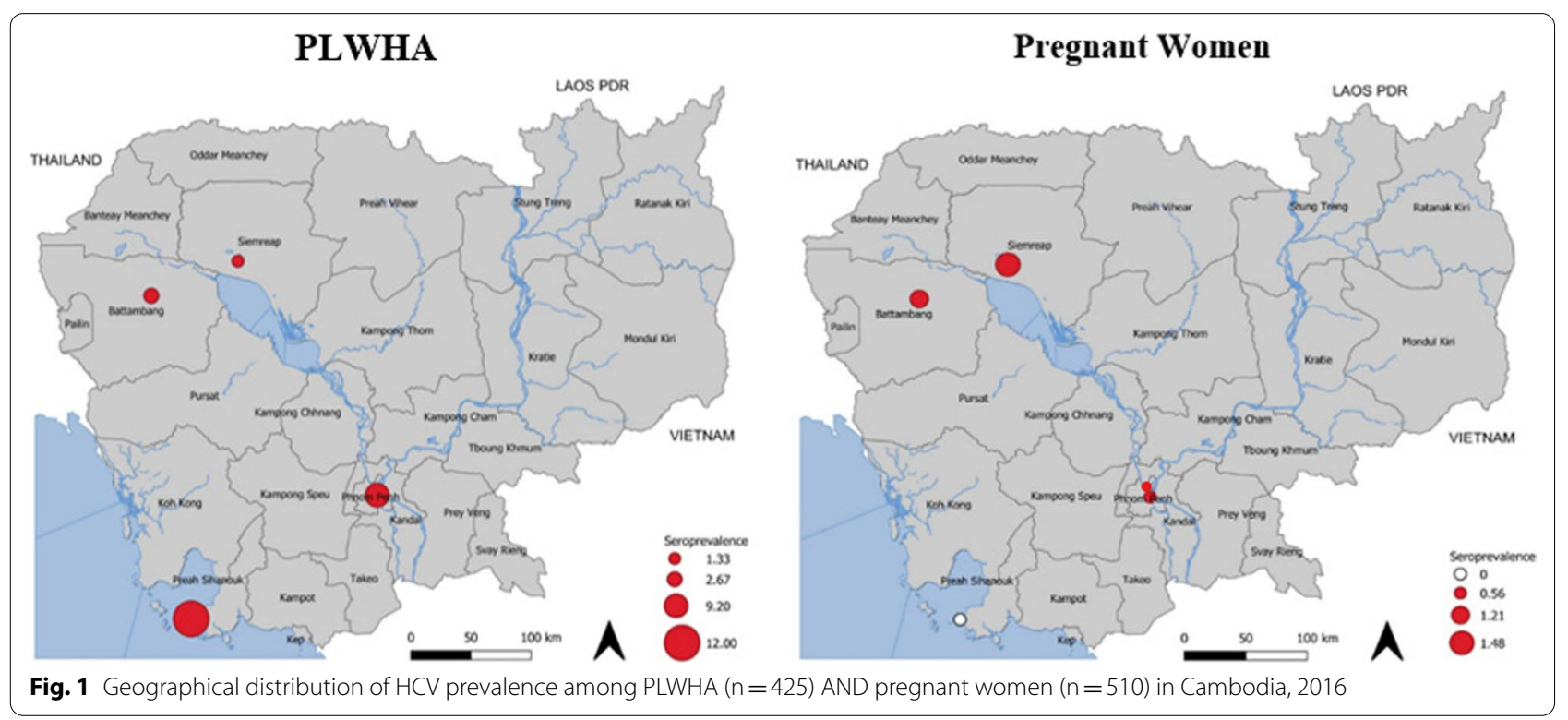


Table 4 Prevalence of Hepatitis C virus antibody per demographic characteristics of participants ( $n=935)$, Cambodia, 2016

\begin{tabular}{|c|c|c|c|c|c|c|}
\hline \multirow[t]{3}{*}{ Characteristics } & \multirow{2}{*}{\multicolumn{2}{|c|}{$\begin{array}{l}\text { PLWHA }(\mathrm{N}=425) \\
\text { Anti HCV positive }\end{array}$}} & \multirow[t]{3}{*}{$P$} & \multirow{2}{*}{\multicolumn{2}{|c|}{$\frac{\text { Pregnant women }(\mathrm{N}=510)}{\text { Anti HCV positive }}$}} & \multirow[t]{3}{*}{$P^{a}$} \\
\hline & & & & & & \\
\hline & $\mathrm{n} / \mathrm{N}$ & $\%$ & & $\mathrm{n} / \mathrm{N}$ & $\%$ & \\
\hline \multicolumn{7}{|l|}{ Education } \\
\hline No formal schooling/less than or primary school & $15 / 198$ & 7.58 & \multirow[t]{3}{*}{0.85} & $4 / 231$ & 1.73 & \multirow[t]{3}{*}{0.39} \\
\hline Secondary school & $6 / 100$ & 6.00 & & $1 / 148$ & 0.68 & \\
\hline High school/University or higher & $8 / 127$ & 6.30 & & 0 & 0.00 & \\
\hline \multicolumn{7}{|l|}{ Marital status } \\
\hline Never married & $2 / 37$ & 5.41 & \multirow[t]{3}{*}{0.84} & 0 & 0.00 & \multirow[t]{3}{*}{1.00} \\
\hline Currently married & $20 / 272$ & 7.35 & & $5 / 499$ & 1.00 & \\
\hline Separated/divorced/Widow & $7 / 116$ & 6.03 & & 0 & 0.00 & \\
\hline \multicolumn{7}{|l|}{ Main occupation } \\
\hline Employee (Government/Non-government) & $8 / 111$ & 7.21 & \multirow[t]{3}{*}{0.59} & $0 / 110$ & 0.00 & \multirow[t]{3}{*}{0.71} \\
\hline Retired/unemployed/home duties & $7 / 76$ & 9.21 & & $1 / 129$ & 0.78 & \\
\hline Farmer/self-employed/others & $14 / 238$ & 5.88 & & $4 / 271$ & 1.48 & \\
\hline \multicolumn{7}{|l|}{ Ever received intra-muscular injection in the past 5 years } \\
\hline No & $12 / 229$ & 5.24 & \multirow[t]{2}{*}{0.16} & 0 & 0.00 & \multirow[t]{2}{*}{0.59} \\
\hline Yes & $17 / 196$ & 8.67 & & $5 / 419$ & 1.19 & \\
\hline \multicolumn{7}{|l|}{ Ever received blood transfusion in the past 5 years } \\
\hline No & $28 / 413$ & 6.78 & \multirow[t]{2}{*}{0.83} & $5 / 506$ & 0.99 & \multirow[t]{2}{*}{1.00} \\
\hline Yes & $1 / 12$ & 8.33 & & 0 & 0.00 & \\
\hline \multicolumn{7}{|l|}{ Ever visited dental clinic in the past 5 years } \\
\hline No & $12 / 222$ & 5.41 & \multirow[t]{2}{*}{0.23} & $4 / 303$ & 1.32 & \multirow[t]{2}{*}{0.65} \\
\hline Yes & $17 / 203$ & 8.37 & & $1 / 207$ & 0.48 & \\
\hline \multicolumn{7}{|c|}{ Ever received intravenous medication injection in the past 5 years } \\
\hline No & $1 / 95$ & 1.05 & \multirow[t]{2}{*}{0.01} & 0 & 0.00 & \multirow[t]{2}{*}{0.33} \\
\hline Yes & $28 / 330$ & 8.48 & & $5 / 368$ & 1.36 & \\
\hline \multicolumn{7}{|l|}{ Having a family member positive for HCV } \\
\hline No & $20 / 394$ & 5.08 & \multirow[t]{2}{*}{$<0.001$} & $5 / 490$ & 1.02 & 1.00 \\
\hline Yes & $9 / 31$ & 29.03 & & 0 & 0.00 & \\
\hline Geographic area & & & & & & \\
\hline Battambang (West) & $2 / 75$ & 2.67 & 0.031 & $2 / 165$ & 1.21 & 0.810 \\
\hline Siem Reap (Northwest) & $1 / 75$ & 1.33 & & $2 / 135$ & 1.48 & \\
\hline Phreah Sihanouk ( Southwest) & $3 / 25$ & 12.00 & & 0 & 0.00 & \\
\hline Phnom Penh (Central) & $23 / 250$ & 9.20 & & $1 / 180$ & 0.56 & \\
\hline
\end{tabular}

${ }^{\text {a }}$ Fisher's exact test

In PLWHA population, anti-HCV prevalence was significantly higher among those who had a history of intravenous medication injection in the past 5 years, at (28/330) 8.4\% [95\% CI: 5.7-12.0] compared to (1/95) 1.0\% [95\% CI: 0.0-5.7]) in those who had not. The same was observed in pregnant women, where all five HCVinfected women reported intravenous medication injection in the past 5 years (5/368) 1.3\% [95\% CI: 0.4-3.1] in those with this history vs. (0/142) $0.0 \%$ [95\% CI: 0.0-0.2.5] in those without. In PLWHA, the anti-HCV prevalence was significantly higher in those who had a family member positive for HCV than in those who did not (9/31) 29.0\% [95\% CI: 14.2-48.0] vs. (20/394) 5.0\% [95\% CI: 3.1-7.7] (Table 4).

\section{Risk factors for HCV}

Table 5 shows the results of crude and adjusted logistic regression on factors associated with $\mathrm{HCV}$ serological status among PLWHA. In bivariate analysis, participants who reported ever received intravenous medication injection in the last 5 years $(\mathrm{OR}=8.7,95 \%$ CI: $1.1-64.9, P=0.04)$ and having a family member positive for $\operatorname{HCV}(\mathrm{OR}=7.6,95 \% \mathrm{CI}$ : 3.1-18.7, $P<0.001)$ were associated with an increased risk of $\mathrm{HCV}$ infection. In 


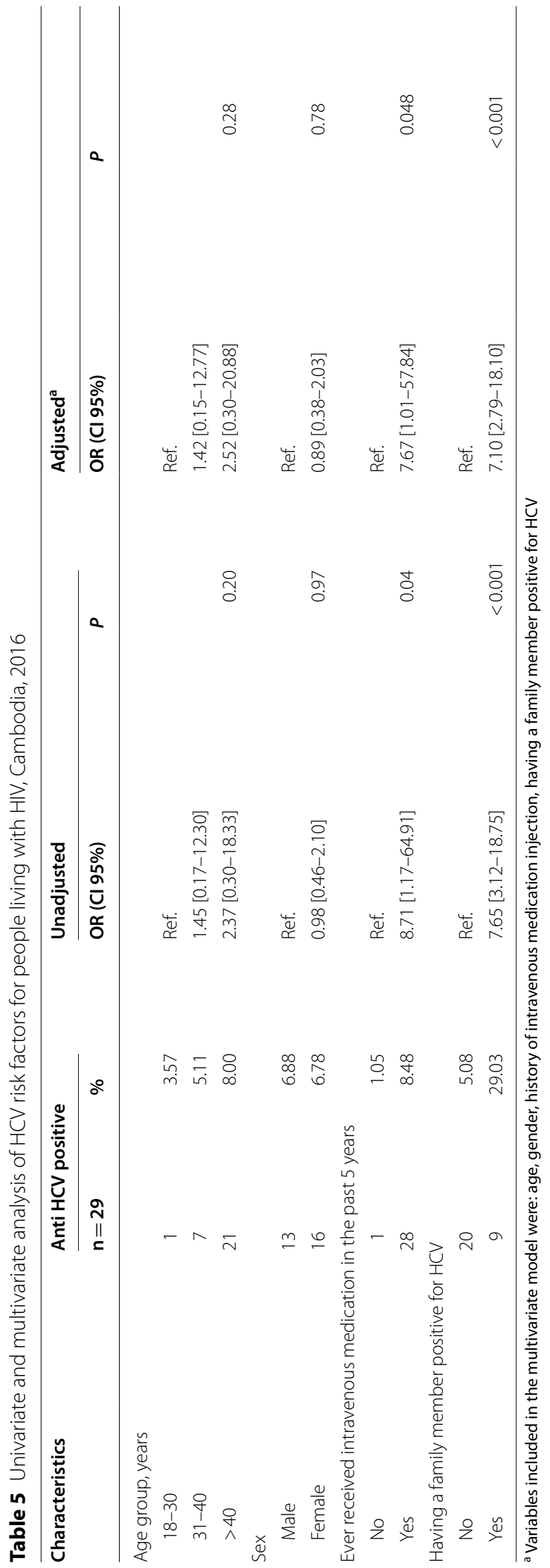


a multivariable model (adjusted for age and sex), HCV infection remained significantly associated with having a family member positive for $\mathrm{HCV}(\mathrm{OR}=7.6$, 95\% CI: $1.0-$ $57.8, P=0.048)$ and a history of intravenous medication injection in the last 5 years $\mathrm{OR}=7.1$ (95\% CI: 2.7-18.1, $P<0.001)$. A multivariable analysis could not be performed among pregnant women due to the small number of HCV-infected women.

\section{Discussion}

To our knowledge, this study represents the first HCV seroprevalence survey conducted in four different provinces of Cambodia evaluating the burden of HCV infection and its risk factors in these two different groups of population (PLWHA and pregnant women).

For PLWHA, HCV seroprevalence was similar to that found in a hospital-based HIV cohort in Phnom Penh at the same calendar period (7.6\%) [6]. The ani-HCV prevalence was slightly higher than that reported in Cambodia in 2014 [11] and in neighboring countries in a regional HIV cohort [12], excluding countries with a high proportion of people who reported that they injected drugs. Chronic HCV infection prevalence among HCV antibody positive was $79 \%$ among PLWHA our study, in line with the rates generally found in newly diagnosed HCV patients [13]. These results might be useful to guide the local strategy development in prioritizing the routine screening plan focusing on most at risk population for HCV case detection and identifying those eligible for treatment.

Our study showed that HCV seroprevalence among pregnant women was $0.9 \%$ [95\% CI: $0.3-2.2]$. This study could not provide the evidence of different distribution across the regions due to small number of positive cases. In a recent seroprevalence study conducted in Battambang province among the general population, antiHCV prevalence was $0.6 \%$ [95\% CI: 0.3-0.9] in adults 18-44 years old [14]. These results confirm the low anti-HCV prevalence (below 1\%) in people under 40 . The currently available literature shows that HCV seroprevalence in the general population reported in previous studies conducted in Cambodia varied over time with a decreasing trend in the most recent years, from $6.5 \%$ in 1993 [14] to $5.8 \%$ in 2012 [15] and $0.6 \%$ in 2018 [10]. The decrease in prevalence of $\mathrm{HCV}$ over time may be explained by a variety of reasons. Since 2000, there has been major improvements in clinical practice in the country, with emphasis on sterilization of medical equipment, use of disposable needles and systematic screening of donated blood, all of which contribute to the reduction of blood borne agents such as $\mathrm{HCV}$ [8]. It should also be noted that the availability of $\mathrm{HCV}$ testing and treatment, both in private sectors and public hospitals with the implementation of HCV program of Médecins Sans Frontières, could also have contributed to the decreasing prevalence of $\mathrm{HCV}$ by reducing the pool of infectious persons $[10,16]$. In addition to that, the low anti-HCV prevalence among young age-group could be explained by the age cohort effect for which people in the old-age group were exposed to $\mathrm{HCV}$ longer than those in the young-age group. The decreased prevalence in younger population was also observed in Thailand $[17,18]$.

In multivariate analyses, ever received intravenous medication injection in the past 5 year and having a family member positive for $\mathrm{HCV}$ were strong, independent risk factors for $\mathrm{HCV}$ infection among Cambodian PLWHA, findings that are consistent with previous studies $[6,8$, 10]. A history of intravenous therapeutic injection was a major risk factor since 33 out of the 34 anti $\mathrm{HCV}$ positive participants reported this practice in the past 5 years, as compared to $665 / 901$ among the negatives. Therapeutic injections are a frequent practice in Cambodia as evidenced by our results showing that three-quarters of the participants, with both PLWHA and pregnant women reporting having received intravenous medication injection over the past 5 years. The overall treatment injection usage rate in Cambodia was 5.9 per person-year (women had a higher rate than men (7.5 vs. 4.3 per person-year), reported as one of the highest overall treatment injection usage rates worldwide [19]. Moreover, having an HCVpositive family member was an independent risk factor for $\mathrm{HCV}$ infection. HCV familial clustering and intra-familial viral transmission have been demonstrated previously in a study by Indolfi et al. [20] and in a Chinese study [21]. In Cambodia, sharing hygienic products, such as shaving razors, toothbrushes and nail clippers or ear/nose piercing or tattoo are common due to ignorance about sanitation and lack of resources. Our results argue in favor of the need of HCV screening for the whole family if one of member is positive and more particularly for children who are currently mostly unaware of access to HCV care programs. The risk factors of $\mathrm{HCV}$ infection could not be analyzed in pregnant women due to sample size issue. Of note, all five $\mathrm{HCV}$-infected pregnant women also reported a history of intravenous medication injection in the previous 5 years.

HCV genotype 1b, 2a and 6 variants were identified. HCV genotype $1 \mathrm{~b}(47.8 \%)$ and 6 (30.4\%) were predominant in the current study. This finding is consistent with several previous studies in Cambodia, which reported $\mathrm{HCV}$ genotype $1 \mathrm{~b}$ and 6 as the common genotypes observed in Cambodia [6, 15, 16, 22, 23]. The genotype 6 variant was also found as the most common in Vietnam and Laos [22], in blood donors in some regions of Thailand [16] and in intravenous drugs users in China [17, 24, 25]. 


\section{Limitations of the study}

This study has several limitations. Our study attempted to assess the anti-HCV prevalence rates in different regions across the country to have representative anti$\mathrm{HCV}$ prevalence rates for the overall population in Cambodia. However, our small sample size in Preah Sihanouk (South-western region) may limit the generalizability of the results for this region. Our findings may have been subject to recall bias or social desirability bias resulting in the underreporting of some risky behaviors and practices over the last 5 years such as the experience of injecting illicit drugs. Last, due to the small number of HCV positive in pregnant women, the risk factors of $\mathrm{HCV}$ infection in this group could not be assessed. However, in this study, we can rule out differential misclassification for assessing the risk factors of $\mathrm{HCV}$ infection linked to the history of risky behaviors and practices, since interviews were done before the result of HCV serology was known.

\section{Conclusions}

In conclusion, we report a high HCV seroprevalence in PLWHA in Cambodia, likely related to past intravenous medication injection and/or intra-familial viral transmission. Our results led the national Cambodia program to offer systematic HCV testing in PLWHA and underline the necessity of care of HCV positive populations, measures which had already been initiated by National Program for adults. Children of $\mathrm{HCV}$-infected parents living in the same household are likely the next target for testing and envisaging care access.

The low prevalence of $\mathrm{HCV}$ infection in the population under 40 years old seems to be confirmed but the anti-HCV prevalence varied across geographical area and specific populations, suggesting the need to set up a surveillance system to assess the anti-HCV prevalence across different population groups.

\begin{abstract}
Abbreviations
PLWHA: People living with HIV/AIDS; HIV: Human immuno-deficiency virus; HCV: Hepatitis C virus; ANC: Antenatal care; Anti-HCV: HCV antibody; HCC: Hepatocellular carcinoma; LMICs: Low-and middle-income countries; WHO: World Health Organization; DAA: Direct-acting agents; HICs: High-income countries; ART: Antiretroviral therapy; UHS: University of Health Sciences; SCO: A signal-to-cutoff; VL: Viral load.
\end{abstract}

\section{Supplementary Information}

The online version contains supplementary material available at https://doi. org/10.1186/s12879-022-07163-2.

Additional file 1: Table S1: seroprevalence and viremic prevalence per sex and per age category $(n=935)$, Cambodia, 2016.

\section{Acknowledgements}

The authors would like to acknowledge all the study participants, the municipality and provincial health departments, ART clinics, Health Centers, Kirby Institute, UNSW and Institute Pasteur in Cambodia for their support in the implementation of the study.

\section{Authors' contributions}

VS, PP, JK, SY, ST conceptualized, designed the study, developed the research protocol and substantively reviewed the manuscript. PP, VS, LM, OS analyzed, interpreted the data and were a major contributor in writing the manuscript. PP, ST, PC have made substantial contributions to the project implementation and the acquisition of data. All authors read and approved the final manuscript.

\section{Funding}

This study was supported by HIV/AIDS Flagship Project, KHANA Center for Population Health Research, Phnom Penh, Cambodia (Grant \#: AID442-A-13-00001) and Fondation Mérieux, France (Grant \#: MF-UHS-HCV-2015). The funder has no role in study design, study implementation and manuscript writing.

\section{Availability of data and materials}

The datasets used and/or analyzed during the current study are available from the corresponding author on reasonable request.

\section{Declarations}

\section{Ethics approval and consent to participate}

This study was approved by the National Ethics Committee for Health Research in Cambodia on 22 /09/2015 (338 NECHR) and in compliance with the principles of the Declaration of Helsinki. Written informed consent was obtained from all participants before the interview and the blood sample collection.

\section{Consent for publication}

Not applicable.

\section{Competing interests}

The authors declare that they have no competing interests.

\section{Author details}

${ }^{1}$ University of Health Sciences, 73 Monivong Boulevard, Phnom Penh 12201, Cambodia. ${ }^{2}$ Ecole Doctorale de Santé Publique, Service de Santé Publique du GH Hôpitaux, Universitaires de Paris Sud, Université Paris-Saclay, Inserm CESP U1018, Paris, France. ${ }^{3}$ KHANA Center for Population Health Research, Phnom Penh, Cambodia. ${ }^{4}$ Saw Swee Hock School of Public Health, National University of Singapore and National University Health System, Singapore, Singapore. ${ }^{5}$ Center for Global Health Research, Touro University California, Vallejo, CA, USA. ${ }^{6}$ Kirby Institute, UNSW Sydney, Sydney, Australia. ${ }^{7}$ Department of Community and Global Health, Graduate School of Medicine, The University of Tokyo, Tokyo, Japan. ${ }^{8}$ Faculty of Social Sciences and Humanity, Royal University of Phnom Penh, Phnom Penh, Cambodia.

Received: 17 November 2021 Accepted: 16 February 2022

Published online: 22 February 2022

\section{References}

1. World Health Organization. Global health sector strategy on viral hepatitis 2016-2021. Towards ending viral hepatitis. 2016; World Health Organization. https://apps.who.int/iris/handle/10665/246177. Accessed 30 October 2021

2. Ford N, Singh K, Cooke GS, Mills EJ, von Schoen-Angerer T, Kamarulzaman $A$, et al. Expanding access to treatment for hepatitis $C$ in resource-limited settings: lessons from HIV/AIDS. Clin Infect Dis. 2012;54(10):1465-72.

3. Petruzziello A, Marigliano S, Loquercio G, Cozzolino A, Cacciapuoti C. Global epidemiology of hepatitis $C$ virus infection: An up-date of the 
distribution and circulation of hepatitis C virus genotypes. World J Gastroenterol. 2016;22(34):7824-40.

4. Mohd Hanafiah K, Groeger J, Flaxman AD, Wiersma ST. Global epidemiology of hepatitis $C$ virus infection: new estimates of age-specific antibody to HCV seroprevalence. Hepatology. 2013;57(4):1333-42.

5. World Health Organization. Global hepatitis report 2017. 2017; World Health Organization. https://www.who.int/publications/i/item/globalhepatitis-report-2017. Accessed 17/11/2021.

6. De Weggheleire A, An S, De Baetselier I, Soeung P, Keath H, So V, et al. A cross-sectional study of hepatitis $C$ among people living with HIV/AIDS in Cambodia: prevalence, risk factors, and potential for targeted screening. PLOS ONE. 2017;12(8):e0183530.

7. Rouet F, Nouhin J, Zheng DP, Roche B, Black A, Prak S, et al. Massive iatrogenic outbreak of human immunodeficiency virus type 1 in Rural Cambodia, 2014-2015. Clin Infect Dis. 2018;66(11):1733-41.

8. Goyet S, Lerolle N, Fournier-Nicolle I, Ken S, Nouhin J, Sowath L, et al. Risk factors for hepatitis $C$ transmission in HIV patients, Hepacam study, ANRS 12267 Cambodia. AIDS Behav. 2014;18(3):495-504.

9. Saing CH, Prem K, Uk P, Chhoun P, Chann N, Tuot S, et al. Risk factors associated with HIV and hepatitis C virus co-infection among people who inject drugs in Cambodia. Int J Drug Policy. 2020;86:102974.

10. Lynch E, Falq G, Sun C, Bunchhoeung PDT, Huerga H, Loarec A, et al. Hepatitis C viraemic and seroprevalence and risk factors for positivity in Northwest Cambodia: a household cross-sectional serosurvey. BMC Infect Dis. 2021;21(1):223.

11. van Griensven J, Phirum L, Choun K, Thai S, De Weggheleire A, Lynen L. Hepatitis B and C co-infection among HIV-infected adults while on antiretroviral treatment: long-term survival, CD4 cell count recovery and antiretroviral toxicity in Cambodia. PLoS ONE. 2014;9(2):e88552.

12. Martinello M, Amin J, Matthews GV, Dore GJ. Prevalence and disease burden of HCV coinfection in HIV cohorts in the Asia Pacific Region: a systematic review and meta-analysis. AIDS Rev. 2016;18(2):68-80.

13. Zhang M, O'Keefe D, Craig J, Samley K, Bunreth V, Jolivet P, et al. Decentralised hepatitis $C$ testing and treatment in rural Cambodia: evaluation of a simplified service model integrated in an existing public health system. Lancet Gastroenterol Hepatol. 2021;6:371-80.

14. Thüring EG, Joller-Jemelka HI, Sareth $H$, Sokhan U, Reth C, Grob P. Prevalence of markers of hepatitis viruses $A, B, C$ and of HIV in healthy individuals and patients of a Cambodian province. Southeast Asian J Trop Med Public Health. 1993;24(2):239-49.

15. Yamada H, Fujimoto M, Svay S, Lim O, Hok S, Goto N, et al. Seroprevalence, genotypic distribution and potential risk factors of hepatitis B and C virus infections among adults in Siem Reap. Cambodia Hepatol Res. 2015;45(4):480-7.

16. Nouhin J, Iwamoto M, Prak S, Dousset JP, Phon K, Heng S, et al. Molecular epidemiology of hepatitis C virus in Cambodia during 2016-2017. Sci Rep. 2019;9(1):7314

17. Wasitthankasem R, Pimsingh N, Treesun K, Posuwan N, Vichaiwattana P, Auphimai $C$, et al. Prevalence of hepatitis $C$ virus in an endemic area of Thailand: burden assessment toward HCV elimination. Am J Trop Med Hyg. 2020;103(1):175-82.

18. Shankar EM, Wasitthankasem R, Posuwan N, Vichaiwattana P, Theamboonlers $\mathrm{A}$, Klinfueng $\mathrm{S}$, et al. Decreasing hepatitis $\mathrm{C}$ virus infection in Thailand in the past decade: evidence from the 2014 National Survey. PLOS ONE. 2016;11(2):e0149362.

19. Vong S, Perz JF, Sok S, Som S, Goldstein S, Hutin Y, et al. Rapid assessment of injection practices in Cambodia, 2002. BMC Public Health. 2005;5:56.

20. Indolfi $G$, Nesi A, Resti M. Intrafamilial transmission of hepatitis C virus. J Med Virol. 2013;85(4):608-14.

21. Luo BF, Rao HY, Gao YH, Wei L. Risk factors for familial clustering of hepatitis $C$ virus infection in a Chinese Han population: a cross-sectional study. BMC Public Health. 2018;18(1):708.

22. Lim SG, Aghemo A, Chen PJ, Dan YY, Gane E, Gani R, et al. Management of hepatitis $C$ virus infection in the Asia-Pacific region: an update. Lancet Gastroenterol Hepatol. 2017;2(1):52-62.

23. Yamamoto C, Nagashima S, Chuon C, Ko K, Huy Do S, Lim O, et al. Substitution of the CD81 Binding Site and $\beta$-Sandwich Area in E2 of HCV in Cambodia. Viruses. 2020:12(5):551.

24. Fu Y, Qin W, Cao H, Xu R, Tan Y, Lu T, et al. HCV 6a prevalence in Guangdong province had the origin from Vietnam and recent dissemination to other regions of China: phylogeographic analyses. PLOS ONE. 2012;7(1):e28006.

25. Zhang Z, Yao Y, Wu W, Feng R, Wu Z, Cun W, et al. Hepatitis C virus genotype diversity among intravenous drug users in Yunnan Province, Southwestern China. PLoS ONE. 2013;8(12):e82598.

\section{Publisher's Note}

Springer Nature remains neutral with regard to jurisdictional claims in published maps and institutional affiliations.
Ready to submit your research? Choose BMC and benefit from:

- fast, convenient online submission

- thorough peer review by experienced researchers in your field

- rapid publication on acceptance

- support for research data, including large and complex data types

- gold Open Access which fosters wider collaboration and increased citations

- maximum visibility for your research: over $100 \mathrm{M}$ website views per year

At BMC, research is always in progress.

Learn more biomedcentral.com/submissions 